\title{
Antibacterial Activity toward Streptococcus mutans and Antioxidant from Traditional Betel Chew Formulation of Indonesia
}

\author{
Endang Verawati ${ }^{1}$, Tri Wardani Widowati ${ }^{2}$, Budi Santoso², Siti Rusdiana Puspa Dewi ${ }^{2}$ and Rindit Pambayun ${ }^{2}$ \\ ${ }^{1}$ Post Graduate Student Student of Postgraduate School Program, Faculty of Agriculture, Sriwijaya University, Indonesia \\ ${ }^{2}$ Lecturer of Postgraduate School Program, Faculty of Agriculture, Sriwijaya University, Indonesia
}

\begin{abstract}
The objective of this research was to determine antibacterial activity toward Streptococcus mutans and antioxidant. Non-Factorial Randomized Block Design method was used in this study. The first stage used nonfactorial randomized block design which consisted of three blocks and six treatments as follows: F1 ( $8 \mathrm{~g}$ betel leaf, $2 \mathrm{~g}$ betel lime), F2 ( $8 \mathrm{~g}$ betel leaf, $2 \mathrm{~g}$ betel lime, $2 \mathrm{~g}$ areca nut, $1 \mathrm{~g}$ gambier), F3 ( $8 \mathrm{~g}$ betel leaf, $2 \mathrm{~g}$ betel lime, $2.5 \mathrm{~g}$ areca nut, $1.5 \mathrm{~g}$ gambier), F4 ( $8 \mathrm{~g}$ betel leaf, $2 \mathrm{~g}$ betel lime, $3 \mathrm{~g}$ areca nut, $2 \mathrm{~g}$ gambier), F5 ( $8 \mathrm{~g}$ betel leaf, $2 \mathrm{~g}$ betel lime , $3.5 \mathrm{~g}$ areca nut, $2.5 \mathrm{~g}$ gambier) and F6 (cefadroxil). The observed parameters in betel chew formulation were antibacterial activity, cellulair metabolites leakage and antioxidant. Results of chemical and microbiological analyses showed that the best treatment was found on F5 treatment ( $8 \mathrm{~g}$ betel leaf, $2 \mathrm{~g}$ betel lime, $3.5 \mathrm{~g}$ areca nut, $2.5 \mathrm{~g}$ gambier) antibacterial activity of $8.25 \mathrm{~mm}$, with antioxidant $\mathrm{IC}_{50}$ of $2.77 \mathrm{mg} / \mathrm{ml}$ and cellulair metabolites leakage of $1.22 \mathrm{~nm}$ (at wave length of $260 \mathrm{~nm}$ ) and $1.51 \mathrm{~nm}$ (at wave length of $280 \mathrm{~nm}$ ), respectively.
\end{abstract}

Keywords: Betel chew extract; Antibacterial; Antioxidant; Streptococcus mutans

\section{Introduction}

Betel chew is mixture of substances such as betel leaf, areca nut, lime and gambier used in betel chew activity.

According to Flora et al. [1], results of research done in England by South Asia Immigrants showed that chewing of betel leaf and areca nut gave freshness feeling, reducing stress and strengthen the teeth. Research results done by Parianti and Ariyasa [2] by using elderly respondents having age of 60 to 89 years which consisted of 37 betel chewers at Batubulan Kangin Village, Sukawati sub district, Gianyar district, showed that the longer the betel chew activity by respondents, the less numbers of dental caries experienced by respondents. The research results in term of the effect of betel chew activity time on dental caries level can be seen in Table 1 .

Mixed materials for betel chew activity are betel leaf, areca nut, lime and gambier that have different nutrient content. Betel leaf is one of traditional medicinal plants having nutrient content as follows: water content of $85.14 \%$, protein of $3.1 \%$, lipid of $0.8 \%$, carbohydrate of $6.1 \%$, fibre of $2.4 \%$, calcium of $230 \mathrm{mg}$, phosphor of $40 \mathrm{mg}$, iron of $7 \mathrm{mg}$, iron ion of $3.5 \mathrm{mg}$, carotene of $96000 \mathrm{IU}$, tamin of $70 \mathrm{mg}$, riboflavin of $30 \mathrm{mg}$, nicotinate acid of $0.7 \mathrm{mg}$, vitamin C of $5 \mathrm{mg}$, tannins of $1.3 \%$, essential oil of $45 \%$ with bethel phenol as its main component $[3,4]$. Betel leaf contains phenol that has role as toxic for microbia by inhibiting enzyme activity from disturber microbial [5]. Nutrient content of areca nut are carbohydrate, lipid, fibre, polyphenol and alkaloid 0.3 to $0.6 \%$, tanin of $15 \%$ and fat of $14 \%$ [6]. According to Mamonto et al. [7], areca nut can be used as antioxidant. Nutrient content of gambier are catechin of 7 to $33 \%$, catechu tannic acid of 20 to $55 \%$, pyrocatecol of 20 to $30 \%$, fluorescence gambier of 1 to $3 \%$, red catechu of 3 to $5 \%$, quersetin of 2 to $4 \%$, fixed oil of 1 to $2 \%$, wax of $1 \%$ to $2 \%$ and alkaloid $<1 \%$ [8].

\begin{tabular}{|c|c|c|c|c|c|}
\hline \multirow{2}{*}{$\begin{array}{c}\text { Betel chew } \\
\text { activity time }\end{array}$} & \multicolumn{5}{|c|}{ Category of dental caries } \\
\cline { 2 - 6 } & Very low & Low & Medium & High & Total \\
\hline 1 to 5 years & 0 & 1 & 14 & 3 & 18 \\
\hline 6 to 10 years & 5 & 1 & 1 & 3 & 10 \\
\hline$>10$ years & 9 & 0 & 0 & 0 & 9 \\
\hline Total & 14 & 2 & 15 & 6 & 37 \\
\hline
\end{tabular}

Table 1: The effect of betel chews activity time on dental caries level.
Gambier can be used as growth inhibitor for bacteria of Streptococcus mutans [9]. Betel lime has chemical formula of $\mathrm{CaOH}_{2}$ (calcium hydroxide) with calcium as its main component so that it can be used to strengthen the teeth [10].

Formulation used in betel chew activity has antimicrobial and antioxidant compounds. Antimicrobia especially bacteria found in teeth is Streptococcus mutans. Antimicrobia is compound that capable to inhibit the growth of microorganisms [11]. Streptococcus mutans is bacteria found in teeth and one of disease caused by Streptococcus mutans is dental caries [12]. Dental caries is infectional disease that destroys teeth structure (enamel). This disease can cause teeth cavity [13]. Antioxidant is a compound that protects cells from damaging due to unstable compound called free radical [14].

Betel chew activity has very beneficial effect on health and teeth. Therefore, identification of antibacterial activity toward Streptococcus mutans as well as antioxidant was done in term of betel chew activity that has very beneficial effect on health and teeth.

The main objectives of this research are as follows to determine the addition of areca nut extract formulation that capable to inhibit the growth Streptococcus mutans bacteria. To determine the addition of areca nut extract formulation that capable to be used as antioxidant.

\section{Materials and Methods}

\section{Design experiment}

Design experiment used in this research was Non-Factorial

*Corresponding author: Endang V, Postgraduate school program, Faculty of agriculture, Sriwijaya University Palembang, South Sumatra, Indonesia, Tel: 62711580068; Fax: 62711 580068; E-mail: endang09verawati@gmail.com

Received November 23, 2017; Accepted December 21, 2017; Published December 28, 2017

Citation: Endang V, Tri Wardani W, Budi S, Siti Rusdiaana Puspa D, Rindit P (2017) Antibacterial Activity toward Streptococcus mutans and Antioxidant from Traditional Betel Chew Formulation of Indonesia. J Microb Biochem Technol 9: 316-320. doi: 10.4172/1948-5948.1000384

Copyright: @ 2017 Endang V, et al. This is an open-access article distributed under the terms of the Creative Commons Attribution License, which permits unrestricted use, distribution, and reproduction in any medium, provided the original author and source are credited. 


\begin{tabular}{|c|c|c|c|c|c|c|}
\hline Materials & F1 & F2 & F3 & F4 & F5 & F6 \\
\hline Betel leaf (g) & 8 & 8 & 8 & 8 & 8 & 0 \\
\hline Betel lime (g) & 2 & 2 & 2 & 2 & 2 & 0 \\
\hline Areca nut (g) & 0 & 2 & 2.5 & 3 & 3.5 & 0 \\
\hline Gambier (g) & 0 & 1 & 1.5 & 2 & 2.5 & 0 \\
\hline Cefadroxil (g) & 0 & 0 & 0 & 0 & 0 & 0.5 \\
\hline
\end{tabular}

Table 2: Formulation of betel chew extract.

Randomized Block Design. Betel chews formulation development process. Treatments level can be seen in Table 2. Betel chew formulation is obtained from survey results related to people who used to do betel chew activity. Treatment for betel chew formulation was increased fourfold from the survey results value because this formulation was not indicating antibacterial capability during preliminary study.

\section{Research procedure}

This research consisted of jelly candy processing procedure according to Rahmi et al. that had been modified as follows [15]:

1. Gambier is mashed and weighed according to treatments, i.e., $1 \mathrm{~g}, 1.5 \mathrm{~g}, 2 \mathrm{~g}, 2.5 \mathrm{~g}$.

2. Areca nut seed is mashed and weighed according to treatments, i.e., $2 \mathrm{~g}, 2.5 \mathrm{~g}, 3 \mathrm{~g}, 3.5 \mathrm{~g}$.

3. Supplementary ingredients for betel chew are weighed, i.e., $2 \mathrm{~g}$ betel lime and $8 \mathrm{~g}$ betel leaves.

4. All weighed ingredients are subsequently blended and water is added up to $40 \mathrm{~mL}$ until homogenous and had dark red color.

5. The blended ingredients are subsequently macerated for $24 \mathrm{~h}$ at room temperature. After $24 \mathrm{~h}$, solution is separated (filtrated) by using saring paper.

\section{Test of antibacterial activity}

Antibacterial activity test according to Goyal et al. [16] was done as follows: Streptococus mutans bacteria is previously rejuvenated by taking bacterial inoculum at slanting agar with magnitude of 1 Ose and then put this preparation into agar media containing nutrient broth and subsequently incubated for $24 \mathrm{~h}$ at temperature of $37^{\circ} \mathrm{C}$. Soft media preparation is done by mixing $1.3 \mathrm{~g}$ nutrients broth and $0.8 \mathrm{~g}$ bacteriological agar followed by addition $100 \mathrm{~mL}$ aquadest and then heated at temperature of $100^{\circ} \mathrm{C}$. On the other hand, hard media preparation is done by mixing $1.3 \mathrm{~g}$ nutrients broth and $1 \mathrm{~g}$ bacteriological agar followed by addition $100 \mathrm{~mL}$ aquadest and then heated at temperature of $100^{\circ} \mathrm{C}$.

Sterilization process at $121^{\circ} \mathrm{C}$ for $15 \mathrm{~min}$ was done to soft media, hard media and equipment used for inoculation. Cold soft media with magnitude of $15 \mathrm{~mL}$ is taken and added with $0.1 \mathrm{~mL}$ of rejuvenated bacteria at concentration $10^{9} \mathrm{cell} / \mathrm{mL}$ and then poured into petri dish. After cold, $15 \mathrm{~mL}$ hard media is poured into petri dish and wait until hardened. Wells is made having $6 \mathrm{~mm}$ in diameter and $4 \mathrm{~mm}$ in depth, whereas betel chew extract to be added was $5 \mu$ l. Petri dish is then incubated within incubator at $37^{\circ} \mathrm{C}$ for $24 \mathrm{~h}$. Observation on antibacterial activity is indicated by clear zone diameter developed in the surrounding extract of betel chew formulation.

\section{Antioxidant analysis on betel chew formulation}

Antioxidant activity was done by using DPPH method according to Kubo et al. [17] and Molyneux [18] as follow:

1. Sample of $1 \mathrm{~mL}$ is taken and added with methanol until total volume of $10 \mathrm{Ml}$;

2. Five dilution series are made from this sample which added with methanol until the volume is $5 \mathrm{~mL}$, i.e., dilution of $0 \mathrm{x}, 0.2 \mathrm{x}$, $0.4 \mathrm{x}, 0.6 \mathrm{x}, 0.8 \mathrm{x}$ and $1 \mathrm{x}$;

3. Diluted sample of $2 \mathrm{~mL}$ is taken and added with $2 \mathrm{~mL} \mathrm{DPPH}$ solution;

4. Sample is subjected to vortex treatment until homogenous;

5. Sample is incubated at $37^{\circ} \mathrm{C}$ for $30 \mathrm{~min}$;

6. Absorbency of sample is determined by using spectrophotometer at $\lambda=517 \mathrm{~nm}$;

Inhibition Percentage (\%) $=\mathrm{x} 100 \%$

Remarks:

$\mathrm{A}_{\text {blank }}$ : Result of spectrophotometer reading at 0 min.

$\mathrm{A}_{\text {sample }}$ : Result of spectrophotometer reading at $30 \mathrm{~min}$.

After inhibition percentage value is obtained, then IC 50 value can be calculated by developing the linear equation from dilution concentration and inhibition percentage. Nilai IC50 value is obtained from $\mathrm{X}$ values of the above linear equation and $\mathrm{Y}$ value is 50 . The linear equation of dilution concentration (as absica values) and inhibition percentage (as ordinate values) can be written as follows:

$$
\mathrm{y}=\mathrm{ax}+\mathrm{b}
$$

\section{Test of cellular metabolite leakage}

The test of cellular metabolite leakage according to Chia et al. is done by using spectrophotometer and absorbency measurement is conducted at $260 \mathrm{~nm}$ wave length (for nitrogen content of nucleate acid) and $280 \mathrm{~nm}$ wave length (for determination of nitrogen content of protein) [19].

The test bacterial suspension of $24 \mathrm{~h}$ old with magnitude of 10 $\mathrm{mL}$ was centrifuged at $3500 \mathrm{rpm}$ for 15 to $20 \mathrm{~min}$ until bacterial cell pellet is obtained. Bacterial cell pellet is then washed two times with phosphate buffer at $\mathrm{pH}$ of 7.0. It is subsequently suspended into $10 \mathrm{~mL}$ solution of phosphate buffer at $\mathrm{pH}$ of 7.4 , connected with betel chew formulation, re-incubated within shaking incubator (at $150 \mathrm{rpm}$ ) for $24 \mathrm{~h}$. After incubation process, this bacterial suspension is centrifuged (disentrifuse) at $3500 \mathrm{rpm}$ for 15 to $20 \mathrm{~min}$; so that centrifuged filtrate is obtained (absorbency is subsequently measured by using spectrophotometer at wave lengths of $260 \mathrm{~nm}$ and $280 \mathrm{~nm}$ ).

\section{Data Analysis}

Data was analyzed by using Analysis of Variance (ANOVA) and followed by HSD (Honestrly Significant Different) test at 5\% level for treatments that have significant effect.

\section{Results}

\section{Test of antibacterial activity}

Antibacterial activity is a compound which used to inhibit the growth of harmful bacteria. The test of antibacterial activity is done by observing the clear zone developed in petri dish. Results of antibacterial activity test showed that the clear zone magnitude was in the range of $0.97 \mathrm{~mm}$ to 25.17 $\mathrm{mm}$. The negative control had clear zone diameter of $0.97 \mathrm{~mm}$, whereas positive control had clear zone diameter of $25.17 \mathrm{~mm}$.

Analysis of variance results related to antibacterial activity test 
Citation: Endang V, Tri Wardani W, Budi S, Siti Rusdiaana Puspa D, Rindit P (2017) Antibacterial Activity toward Streptococcus mutans and Antioxidant from Traditional Betel Chew Formulation of Indonesia. J Microb Biochem Technol 9: 316-320. doi: 10.4172/1948-5948.1000384

showed that betel chew extract formulation had significant effect on antibacterial activity. Results of HSD test at $5 \%$ level related to treatment effect on antibacterial activity can be seen in Table 3 .

Results of HSD test at 5\% level (Table 3) showed that F6 (Cefadroxil) treatment as positive control and F1 ( $8 \mathrm{~g}$ betel leaves, $2 \mathrm{~g}$ betel lime) treatment as negative control were significantly different than other treatments.

\section{Antioxidant analysis}

Antioxidant is a compound that protect cell from damage due to unstable compounds which commonly called as free radical [14]. Antioxidantanalysis is done by using DPPH (2,2-difenil-1-pikrilhidrazil) method to measure IC50 (Inhibitory concentration) as concentration of test compound that capable to inhibit $50 \%$ of free radicals. The smaller the IC50 value, the highest the activity of free radical inhibition. Antioxidant analysis test is done by observing absorbency value using spectrophotometer UV-Vis [18].

Results of antioxidant test were in the range of $4.08 \mathrm{mg} / \mathrm{ml}$ to 2.77 $\mathrm{mg} / \mathrm{ml}$. The negative control had antioxidant of $4.38 \mathrm{mg} / \mathrm{ml}$, whereas positive control had antioxidant of $1.46 \mathrm{mg} / \mathrm{ml}$. Analysis of variance results in term of antioxidant values showed that treatment of betel chew extract formulation had significant effect on antioxidant. HSD test results at $5 \%$ level of treatment effect on antioxidant can be seen in Table 4.

HSD test (Table 3) showed that average value of antioxidant activity for F6 (Cefadroxil) treatment as positive control was significantly different than that of other treatments. This table showed that the higher the betel chew concentration, the lower the antioxidant concentration value. The IC50 value on F5 treatment ( $8 \mathrm{~g}$ betel leaves, $2 \mathrm{~g}$ betel lime, $3.5 \mathrm{~g}$ areca nut, $2.5 \mathrm{~g}$ gambier) had concentration of $2.77 \mathrm{mg} / \mathrm{ml}$. The lowest $\mathrm{IC}_{50}$ value was found on F2 treatment ( $8 \mathrm{~g}$ betel leaves, $2 \mathrm{~g}$ betel lime, $2.0 \mathrm{~g}$ areca nut, $1 \mathrm{~g}$ gambier).

\section{Analysis of cellular metabolite leakage}

The cellular metabolite leakage is bacterial cell damage that can affect metabolism function of cells and severe damaging level can results in death of bacterial cell [20]. Bacterial cell damage can results in damage of membrane permeability and produce leakage on intracellular components such as natrium glutamate, natrium hydrogen phosphate, nucleotide, potassium and organic phosphate.

The leakage of cells can be observed by measuring level of cell membrane damage, from numbers of $\mathrm{K}^{+}$ions within cell plasma or from ingredients released by cell that can be absorbed at wave lengths of 260 $\mathrm{nm}$ and $280 \mathrm{~nm}$. The increase of measured absorbency value indicates the increase of released cell content. According to Park et al. [21], component of released cell content measured at $260 \mathrm{~nm}$ wave length was DNA such as purine, pyrimidine and ribonucleotide, whereas tyrosine and tryptophan can be measured at $280 \mathrm{~nm}$ wave length [21] The cellular metabolite leakage is observed from leakage of protein and nucleate acid.

Analysis of variance related to leakage test value of cellular metabolite at $260 \mathrm{~nm}$ wave length showed that betel chew extract formulation had significant effect on cellular metabolite leakage. HSD test results at 5\% level Hasil uji BNJ 5\% in term of treatments effect on cellular metabolite leakage can be seen in Table 5 .

HSD test (Table 5) showed that the highest average value of cellular

\begin{tabular}{|c|c|c|}
\hline Treatment of betel chew formulations & Average diameter of clear zone $(\mathrm{mm})$ & HSD $5 \%=1.83$ \\
\hline $\mathrm{F} 1$ ( $8 \mathrm{~g}$ betel leaf, $2 \mathrm{~g}$ betel lime) & 0.97 & a \\
\hline F2 ( $8 \mathrm{~g}$ betel leaf, $2 \mathrm{~g}$ betel lime, $2 \mathrm{~g}$ areca nut, $1 \mathrm{~g}$ gambier $)$ & 4.83 & $\mathrm{~b}$ \\
\hline $\mathrm{F} 3$ ( $8 \mathrm{~g}$ betel leaf, $2 \mathrm{~g}$ betel lime, $2.5 \mathrm{~g}$ areca nut, $1.5 \mathrm{~g}$ gambier) & 5.33 & $\mathrm{~b}$ \\
\hline F4 ( $8 \mathrm{~g}$ betel leaf, $2 \mathrm{~g}$ betel lime, $3 \mathrm{~g}$ areca nut, $2 \mathrm{~g}$ gambier) & 8 & $\mathrm{~cd}$ \\
\hline $\mathrm{F} 5$ ( $8 \mathrm{~g}$ betel leaf, $2 \mathrm{~g}$ betel lime, $3.5 \mathrm{~g}$ areca nut, $2.5 \mathrm{~g}$ gambier) & 8.25 & $\mathrm{~d}$ \\
\hline F6 (Cefadroxil) & 25.17 & e \\
\hline
\end{tabular}

Remarks: Numbers followed by the same letters at the same columns are not significantly different

Table 3: HSD Test of treatment effect on anticabterial activity.

\begin{tabular}{|l|c|c|}
\hline Treatment of betel chew formulations & Antioxidant concentration $\mathbf{n}(\mathbf{m g} / \mathbf{m l})$ & $\mathbf{1 . 4 6}$ \\
\hline F6 (Cefadroxil) & 2.77 \\
\hline F5 (8 $\mathrm{g}$ betel leaf, $2 \mathrm{~g}$ betel lime, $3.5 \mathrm{~g}$ areca nut, $2.5 \mathrm{~g}$ gambier) & 2.98 \\
\hline F4 $(8 \mathrm{~g}$ betel leaf, $2 \mathrm{~g}$ betel lime, $3 \mathrm{~g}$ areca nut, $2 \mathrm{~g}$ gambier) & 3.18 \\
\hline F3 $(8 \mathrm{~g}$ betel leaf, $2 \mathrm{~g}$ betel lime, $2.5 \mathrm{~g}$ areca nut, $1.5 \mathrm{~g}$ gambier) & $\mathrm{a}$ \\
\hline F2 $(8 \mathrm{~g}$ betel leaf, $2 \mathrm{~g}$ betel lime, $2 \mathrm{~g}$ areca nut, $1 \mathrm{~g}$ gambier) & 4.08 \\
\hline F1 $(8 \mathrm{~g}$ betel leaf, $2 \mathrm{~g}$ betel lime) & $\mathrm{b}$ \\
\hline
\end{tabular}

Remarks: Numbers followed by the same letters at the same columns are not significantly different

Table 4: HSD Test of treatment effect on antioxidant.

\begin{tabular}{|c|c|c|}
\hline Treatment & Average (nm) & HSD $5 \%=0.036$ \\
\hline F6 (Cefadroxil) & 1.24 & a \\
\hline $\mathrm{F} 5$ ( $8 \mathrm{~g}$ betel leaf, $2 \mathrm{~g}$ betel lime, $3.5 \mathrm{~g}$ areca nut, $2.5 \mathrm{~g}$ gambier) & 1.22 & a \\
\hline $\mathrm{F} 4$ ( $8 \mathrm{~g}$ betel leaf, $2 \mathrm{~g}$ betel lime, $3 \mathrm{~g}$ areca nut, $2 \mathrm{~g}$ gambier $)$ & 1.2 & $b$ \\
\hline $\mathrm{F} 3$ ( $8 \mathrm{~g}$ betel leaf, $2 \mathrm{~g}$ betel lime, $2.5 \mathrm{~g}$ areca nut, $1.5 \mathrm{~g}$ gambier $)$ & 1.18 & $\mathrm{~cd}$ \\
\hline F2 ( $8 \mathrm{~g}$ betel leaf, $2 \mathrm{~g}$ betel lime, $2 \mathrm{~g}$ areca nut, $1 \mathrm{~g}$ gambier $)$ & 1.18 & cd \\
\hline $\mathrm{F} 1$ ( $8 \mathrm{~g}$ betel leaf, $2 \mathrm{~g}$ betel lime) & 1.13 & de \\
\hline Control & 0.29 & $\mathrm{e}$ \\
\hline
\end{tabular}

Remarks: Numbers followed by the same letters at the same columns are not significantly different

Table 5: HSD Test of cellular metabolite leakage at $260 \mathrm{~nm}$ wave length. 


\begin{tabular}{|c|c|c|}
\hline Treatment & Average (nm) & HSD $5 \%=0.036$ \\
\hline F6 (Cefadroxil) & 1.55 & a \\
\hline F5 ( $8 \mathrm{~g}$ betel leaf, $2 \mathrm{~g}$ betel lime, $3.5 \mathrm{~g}$ areca nut, $2.5 \mathrm{~g}$ gambier) & 1.51 & a \\
\hline $\mathrm{F} 4$ ( $8 \mathrm{~g}$ betel leaf, $2 \mathrm{~g}$ betel lime, $3 \mathrm{~g}$ areca nut, $2 \mathrm{~g}$ gambier $)$ & 1.5 & a \\
\hline $\mathrm{F} 3$ ( $8 \mathrm{~g}$ betel leaf, $2 \mathrm{~g}$ betel lime, $2.5 \mathrm{~g}$ areca nut, $1.5 \mathrm{~g}$ gambier) & 1.46 & $b$ \\
\hline F2 ( $8 \mathrm{~g}$ betel leaf, $2 \mathrm{~g}$ betel lime, $2 \mathrm{~g}$ areca nut, $1 \mathrm{~g}$ gambier) & 1.46 & b \\
\hline F1 (8 g betel leaf, $2 \mathrm{~g}$ betel lime) & 1.43 & $\mathrm{~cd}$ \\
\hline Control & 0.39 & $\mathrm{~d}$ \\
\hline
\end{tabular}

Remarks: Numbers followed by the same letters at the same columns are not significantly different

Table 6: HSD Test of Cellular Metabolite Leakage at $280 \mathrm{~nm}$ wave length.

metabolite leakage was found on F5 treatment ( $8 \mathrm{~g}$ betel leaves, $2 \mathrm{~g}$ betel lime, $3.5 \mathrm{~g}$ areca nut, $2.5 \mathrm{~g}$ gambier) with magnitude of $1.22 \mathrm{~nm}$ and the lowest one was found on F2 treatment ( $8 \mathrm{~g}$ betel leaves, $2 \mathrm{~g}$ betel lime, 2 $\mathrm{g}$ areca nut, $1 \mathrm{~g}$ gambier).

Analysis of variance related to value of cellular metabolite leakage test at $280 \mathrm{~nm}$ wave length showed that betel chew extract formulation had significant effect on cellular metabolite leakage. HSD test at 5\% level of treatment effect on cellular metabolite leakage can be seen in Table 6.

\section{Discussion}

The result of Tukey 5\% (Table 3) showed that clear zone of streptococcus mutan was increased as it increased the concentration of gambir. According to Pambayun et al. [22] and Akiyama et al. [23], catechins compound in gambier and tannin compound in areca nut are effective to inhibit Gram-positive bacteria because catechins in gambier and tannin in areca nut bind with peptide units on peptidoglycan component from cell walls which in turn disturb the integrity of bacterial cell walls and cause bacterial cell leakage [22,23]. The damage on bacterial cell walls results in disturbance of metabolism process and subsequently the death of cells [24]. According to Ngajow, peptidoglycan is composer of bacterial cell walls which develop rigid bacterial cells and bacteria can survive at osmosis pressure condition that is not appropriate with the condition inside cells. Peptidoglycan formation is aided by periplasm enzymes consisting of trans glycosilase, trans peptidase and carboxypeptidase [25]. Catechins and tanin inhibit transpeptidase enzyme which has function to combine between 1 unit of peptidoglycan and other units during peptidoglycan formation of bacterial cell walls.

The defect of cell wall affected cell leakage. Based on tukey $5 \%$ test (Tables 5 and 6) showed that cell leakage in Streptococcus mutans bacteria due to quinine extract as antibacterial protein released higher than nucleic acid, it was because bacterial cells leaked more protein compound than nucleic acid.

Bacterial cell leakage was due to the use of betel chew extract consisting of betel lime, betel leaves, areca nut and gambier. The compounds that have role in damaging of bacterial cell were gambier and areca nut which contain catechin and tannin compound having antibacterial characteristics.

According to Trombetta et al. [26], bacterial cell leakage is occurred due to damage of hydrophobic bond as membrane structural component. Kim et al. [27] had stated that cell leakage is occurred due to damage of hydrophobic bond which consisted of membrane structural component such as protein and phospholipid as well as dissolving of other components which bound in hydrophilic and hydrophobic manners. Yuk and Marshall [28] also stated that this condition could increase cell membrane permeability which facilitate entry of anti- bacterial components into cells and discharge of cell substance such as protein and nucleate acid which results in damaging of cells.

Catechin and tannin compounds had an influence on antioxidant activity. The results of Tukey $5 \%$ test (Table 4 ) showed that the more concentrated gambir and betel nut used were the higher antioxidant activity produced. The ability of antioxidant activity is influenced by the number of hydroxyl groups in a bioactive compound. Catechins and tannins are polyphenols that have more than one hydroxyl group. Compounds containing hydroxyl groups $(-\mathrm{OH})$ will donate hydrogen atoms $(\mathrm{H})$ to radical compounds or convert more stable radical compounds [29].

$\mathrm{C}$ vitamin at antioxidant activity test has a role as positive control and $\mathrm{C}$ vitamin ability as antioxidant had absorbency value of 0.00486 $\mathrm{mg} / \mathrm{mL}(4.86 \mathrm{ppm})$. The ability of antioxidant activity is affected by numbers of hydroxyl group in a bioactive compound. A compound containing $\mathrm{OH}^{-}$group in its heterolytic splitting will produce $\mathrm{O}^{-}$and $\mathrm{H}^{+}$. This hydroxyl group release hydrogen ions that will react with DPPH free radicals so that it can inhibit free radical from DPPH and subsequently produce 1,1-difenil-2-dipycrylhydrazine (DPPH-H) [29].

\section{Conclusion}

It can be concluded that concentration of betel chew extract formulation that capable to inhibit the growth of Streptococus mutans with magnitude of $8.25 \mathrm{~mm}$ was F5 treatment ( $8 \mathrm{~g}$ betel leaves, $2 \mathrm{~g}$ betel lime, $3.5 \mathrm{~g}$ areca nut, $2.5 \mathrm{~g}$ gambier) and had antioxidant activity value of $2.77 \mathrm{mg} / \mathrm{ml}$ as well as cellular metabolite leakage values of $122 \mathrm{~nm}$ (260 nm wave length) and $1.51 \mathrm{~nm}(280 \mathrm{~nm}$ wave length), respectively.

\section{Acknowledgement}

The researcher would like to thank Dipa Research Project Unsri for financial support.

\section{References}

1. Flora M, Tylor C, Rahman M (2012) Betel quid chewing and its risk factors in Bangladeshi adults. WHO South East-Asia J Pub Health 1: 162-181.

2. Parianti N, Ariyasa I (2015) Relationship of betel chewing habit on dental caries occurrence for elderly people at Batu Bulan Kangin village. Virgin J 1: 200-208.

3. Prastyowati A, Purwijantiningsih E, Pranata S (2014) Chemical and microbiological quality of hard candy of green betel leaf (Piper betle L.) as additional feed for livestock. J Sain Veteriner 32: 126-421.

4. Rosman R, Suhirman (2016) Betel as medicinal plant requires improvement of cultivation technology. Res Dev New Indus Plant 12: 13-15.

5. Lutviandhitarani G, Harjanti, Wahyono F (2015) Green antibiotic of betel leaf (Piper betle L.) as substitution for commercial antibiotics for mastitis handling J Agripet 15: 28-32.

6. Harnowo I, Yunianta (2015) Addition of areca nut seed extract and citric acid on physical, chemical and organoleptical characteristics of sweet star fruit juice. J Food Agroindus 3: 1241-1251.

7. Mamonto S, Runtuwene, Wehantouw F (2014) Antioxidant activity of seed 
Citation: Endang V, Tri Wardani W, Budi S, Siti Rusdiaana Puspa D, Rindit P (2017) Antibacterial Activity toward Streptococcus mutans and Antioxidant from Traditional Betel Chew Formulation of Indonesia. J Microb Biochem Technol 9: 316-320. doi: 10.4172/1948-5948.1000384

skin extract of Yaki areca nut (Areca vestiaria G.) extracted by using soxhlet method. J Pharm Sci 3: 263-272.

8. Isnawati A, Raini M, Sampurn O, Mutiatikum, Widowati L, et al. (2012) Characterization of three types of gambir extract (Uncaria gambir Roxb.) from west Sumatra. J Bul Res Heal 40: 201-208.

9. Pambayun R, Gardjito M, Sudarmadji S, Rahayu K (2008) Sensitivity of gram positive bacteria to catechin extracted from gambir (Uncaria gambir). Agritech 28: $175-179$

10. Alphianti L (2014) Apexification curing with calcium hydroxide paste: Evaluation during 12 months. J IDJ 3: 52-59.

11. Gupta C, Prakash D, Gupta S (2014) Studies on the antimicrobial activity of Tamarind (Tamarindus indica) and its potential as food bio-preservative. Int $\mathrm{J}$ Food Res 21: 2437-2441.

12. Nishimura J, Saito T, Yoneyama H, Isogai E (2012) Biofilm formation by Streptococcus mutans related bacteria. J Adv Microbiol 2012: 208-215.

13. Ryan L (2015) Dental caries: A current understanding and implications. J Nat Sci 1:1-4.

14. Hamid AA, Usman LA, Aiyelaagbe O, Lawal A (2010) Antioxidants: Its medicinal and pharmacological applications. J Pure Appl Chem 4: 142-151.

15. Rahmi SL, Tafzi F, Anggraini S (2012) The effect of gelatine addition on jelly candy processing from rosella flower (Hibiscus sabdariffa Linn). Res J Jambi University Sci Ser 14: 37-44.

16. Goyal P, Chauhan A, Kaushik (2009) Laboratory evaluation of crude extracts of Cinnamomum tamala for potential antibacterial activity. J Elec Bio 5: 75-79.

17. Kubo I, Masuoka N, Xiao P, Haraguchi H (2002) Antioxidant activity of dodecyl gallate. J Agric Food Chem 50: 3533-3539.

18. Molyneux $P$ (2004) The use of the stable free radical diphenylpicryl-hydrazy (dpph) for estimating antioxidant activity. Songklanakarin. J Sci Tech 26: 211 219
19. Chia M, Preston J, Wei C (2000)Antibacterial mechanism of allyl isothiocyanate. J Food Protect 63: 727-734.

20. Asriani, Laksmi SA, Yasni S, Sudirman I (2007) Anti-bacterial mechanisms of metabolites of $\mathrm{lb}$. plantarum kikand monoacylglycerol of coconut oil on food pathogen bacteria. J Food Indust Tech18: 126-132.

21. Park SJ, Park HW, Park J (2003) Inactivation kinetic pf food poisoning microorganisms by carbon dioxide and high hydrostatic pressure. J Food Scince 68: 976-981.

22. Pambayun R, Gardjito M, Sudarmadji S, Rahayu K (2007) Phenol content and antibacterial characteristics of several types of gambir product extracts (Uncaria gambir Roxb). Indonesia Pharm Mag 18: 141-146.

23. Akiyama H, Fujii K, Yamasaki O, Oono T, Iwatsuki K (2001) Anti-bacterial action of several tannin against Staphylococcus aureus. J Antimicrobiol Chem 48: 487-491.

24. Taylor P, Miller J, Stapleton P (2009) Antimicrobial properties of green tea catechins. Food Sci Tech Bul 2: 71-81.

25. Morelli C, Calvio C, Biagiotti M, Speranza G (2014) pH-dependent hydrolase, glutaminase, transpeptidase and autotranspeptidase activities of Bacillus subtilis-glutamyl transferase. J FEBS 281: 232-245.

26. Trombetta D, Saija A, Bisignano G, Arena S, Caruso S, et al. (2005) Mechanisms of antibacterial action of three monoterpenes. J Antimicrob Agent Chem 49: 2474-2478.

27. Kim J, Marshal M, Wei C (1995) Antibacterial activity of some essential components against five food borne pathogens. J Agric Food Chem 43: 28392845 .

28. Yuk H, Marshall D (2005) Influence of acetic, citric and lactic acid on Escherichia coli o $157 \mathrm{~h} 7$ membrane lipid composition, verotoksin secretion and acid resistance in simulated gastric fluid. J Food Protect 68: 673-679.

29. Petrina R, Alimuddin AH, (2017) Test of antioxidant activity and toxicity of seed skin of areca nut (Areca catechu L.). 6: 70-77. 